\title{
Effects of Bacterial Inoculants and Cutting Height on Fermentation Quality of Barley Silage
}

Hyuk Jun Lee ${ }^{1}$, Dong Hyeon $\mathrm{Kim}^{1}$, Sadar M. Amanullah ${ }^{1,3}$, Sam Churl Kim², Young Min Song ${ }^{2}$ and Hoi Yun Kim² ${ }^{1}$ Division of Applied Life Science (BK21Plus, Insti. of Agri. \& Life Sci.), Gyeongsang National University, Jinju 660-701, South Korea, ${ }^{2}$ Department of Animal Resource Technology, Gyeongnam National University of Science and Technology, Jinju 660-758, South Korea, ${ }^{3}$ Bangladesh Livestock Research Institute, Savar, Dhaka-1314, Bangladesh

\begin{abstract}
This study was conducted to investigate the effects of bacterial inoculation (Lactobacillus plantarum) and cutting height on the chemical composition, fermentation characteristics and in vitro dry matter digestibility (IVDMD) in whole crop barley silage. Barley forage (Youngyang hybrid) was harvested at about $27 \%$ of dry matter (DM) level at two different cutting height (5 vs. 15 $\mathrm{cm})$. And it was chopped to $5 \mathrm{~cm}$ length and treated with or without L. plantarum. Four replicates of each treatment were ensiled into $10 \mathrm{~L}$ mini silo $(3 \mathrm{~kg})$ for 100 days. After 100 days, bacterial inoculation decreased $(\mathrm{p}=0.001)$ DM content, while increased cutting height increased $(\mathrm{p}=0.002) \mathrm{DM}$ in uninoculated silage. Crude protein $(\mathrm{CP})$ concentration was decreased by increasing height in uninoculated silage (8.84 vs. 8.16) but increased in inoculated silage (8.19 vs. 8.99). Both neutral detergent fiber (NDF) ( $<<0.011)$ and acid detergent fiber $(\mathrm{ADF})(\mathrm{p}<0.004)$ were decreased by increasing cutting height of forage at harvest. The IVDMD and ammonia- $\mathrm{N}$ was increased $(\mathrm{p}=0.001)$ by increasing cutting height and inoculation, respectively. Lactic acid bacteria (LAB) was increased $(p=0.002)$ in inoculated silage, but yeast count was decreased $(p=0.026)$ in uninoculated silages. It is concluded that increased cutting height of forage at harvest could be useful to make a fibrous portion with increase of dry matter digestibility of silages.
\end{abstract}

(Key words : Barley, Cutting height, Lactobacillus plantarum, Silage)

\section{I . INTRODUCTION}

The forage is indispensable resources for normal development of the rumen in ruminants. High quality forage is known as a key resource to improve the animal productivity (Kim et al., 2012). Oba and Allen (1999) reported that increased neutral detergent fiber (NDF) digestibility improved dry matter(DM) intake and $4 \%$ fat-corrected milk. Also high quality forage can replace some parts of concentrate from mixed feed (Seo et al., 2010).

In South Korea, more than $80 \%$ of demanded forage is producing in domestic, and the ensiling is the main procedure for forage preservation (McDonald et al., 1991). Barley is widely used to make silage in Korea for its high proportion of rumen-fermentable carbohydrates (Eun et al., 2004). Therefore, improving the nutritive quality and digestibility of barley silage has considerable importance for beef and dairy producers.
Usually extended wilting time lead to decreases of silage quality (Kim and Adesogan, 2006). In Korea, barley forage usually wilted for one or two days to adjust moisture content. However, it is hard to wilt quickly due to frequent rain during harvesting season. With this reason, increases of cutting height may increase the aeration at the bottom of harvested forages layed down at the field, which could help to increase silage quality by decreased wilting time. Moreover, increasing cutting height from the ground helps to improve fiber digestibility (Tolera and Sundstøl, 1999). $\mathrm{Wu}$ and Roth (2005) also reported that increase in cutting height of corn at harvest, crude protein $(\mathrm{CP})$ concentration and NDF digestibility was improved in following silage.

Using bacterial inoculants is another approach to improve the silage fermentation and nutrient digestibility. Numerous precedence studies showed that bacterial inoculants are used in silage to stimulate lactic fermentation, decreasing $\mathrm{pH}$ and thereby improving silage preservation (Seale, 1986; Filya et

* Corresponding author: Sam Churl Kim, Division of Applied Life Science (BK21Plus, Insti. of Agri. \& Life Sci.), Gyeongsang National University, Jinju 660-701, South Korea.

Tel. +82-55-772-1947, Fax: +82-55-772-1949, E-mail: kimsc@gnu.ac.kr 
al., 2000; Baah et al., 2011). Considerable studies were carried out to determine the effect of bacterial inoculants or cutting height separately, however, the effect of bacterial inoculants and cutting height together on silage quality was not studied.

Therefore, this study was carried out to determine the effect of applying inoculants in barley forage harvested at different cutting height on nutritive value and fermentation quality of barley silage.

\section{П. MATERIALS AND METHODS}

\section{Preparation of silage}

Barley forage (Youngyang hybrid) was grown at the animal research unit, Gyeongsang National University, South Korea and harvested at about $27 \%$ of DM level at two different cutting height (5 vs. $15 \mathrm{~cm})$. Forage was chopped by conventional forage harvester (BHC-90, BUHEUNG Machinery Ind Co., Korea) to $5 \mathrm{~cm}$ theoretical cut and treated forage from both cutting height with or without inoculants. The inoculants (Chungmi-Lacto, CMbio) applied at $0.02 \mathrm{~g} / \mathrm{kg}$ of fresh forage to supply $1.2 \times 10^{3} \mathrm{cfu} / \mathrm{g}$ of $L$. plantarum. Four replicates of each treatment were ensiled into $10 \mathrm{~L}$ mini silo $(3 \mathrm{~kg})$ for 100 days at room temperature in an enclosed barn.

\section{Laboratory analysis}

At the day of silage making and at silo opening, fresh treated forage and silage $(500 \mathrm{~g})$, respectively, were subsampled for chemical analysis. A portion $(20 \mathrm{~g})$ of silage was macerated in laboratory blender along with $200 \mathrm{ml}$ of distilled water to make silage extract, which was used for $\mathrm{pH}$, ammonia-N and volatile fatty acid (VFA) determination, microbial enumeration and microbial DNA extraction. Samples were dried at $60^{\circ} \mathrm{C}$ for $48 \mathrm{~h}$, ground to pass $1-\mathrm{mm}$ screen of a grinder (Cutting Mill, SHINMYUNG ELECTRIC Co., Ltd, South Korea). Dry matter was determined in dry oven at $100^{\circ} \mathrm{C}$ for $24 \mathrm{~h}$. The nitrogen and ether extract (EE) contents were determined by Kjeldahl procedure using $\mathrm{N}$ analyzer(B-324, 412, 435 and $719 \mathrm{~S}$ Titrino, BUCHI, Germany) and Soxhlet procedure (AOAC, 1990), respectively.
Concentrations of NDF and acid detergent fiber (ADF) were analyzed as described by Van Soest et al. (1991) using an AnKom Fiber Analyzer (A220, AnKom Techology). Alfaamylase and sodium sulfite were used for NDF determination. In vitro DM digestibility (IVDMD) was measured by the method of Tilley and Terry (1963) using ANKOM DAISY ${ }^{\mathrm{II}}$ incubator (ANKOM Technology, USA). The $\mathrm{pH}$ was measured with electric $\mathrm{pH}$ meter (SevenEasy, Mettler Toledo, Swizerland) and ammonia-N was analyzed by colorimetry (Chaney and Marbach, 1962). The concentrations of VFA were measured using HPLC(L-2130, HITACHI) with an auto-sampler(L-2200, HITACHI), UV detector (L-2400, HITACHI) and a column (MetaCarb $87 \mathrm{H}$, Varian) by the method of Muck and Dickerson (1988).

\section{Microbiological count}

The counts of Lactic acid bacteria, yeast and mold were carried out with using silage extract, considered it as the first dilution. The lactobacilli MRS agar medium(MRS; Difco, Detroit, MI, USA) used for the isolation and count of lactic acid bacteria, and potato dextrose agar medium (PDA; Difco, Detroit, MI, USA) used for the isolation and count of yeasts and molds. Lactobacilli MRS agar mediums was placed in a $\mathrm{CO}_{2}$ incubator (Thermo Scientific, USA) at $39^{\circ} \mathrm{C}$ for $24 \mathrm{~h}$ and PDA mediums was incubated at $39^{\circ} \mathrm{C}$ for $24 \mathrm{~h}$ in normal incubator (Johnsam Corporation, Korea). Visible colonies were counted from the agar medium at appropriate dilutions and the number of colony forming units (CFU) was expressed per gram of silage.

\section{DNA Extraction, primers and PCR conditions}

Extraction of genomic DNA was conducted by using QIAamp DNA mini kit (Qiagen, USA) following the manufacturer's protocol and concentrations were measured by using a NanoDrop Spectrophotometer (ND-1000, USA). A Bio-Rad C1000 Touch $^{\mathrm{TM}}$ Thermal cycler real-time PCR detection system $\left(\mathrm{CFX} 96^{\mathrm{TM}}\right.$ Real-Time system, Bio-Rad Laboratories, Inc., Hercules, CA, USA) was used to amplify DNA. Amplification conditions and primers for $L$. plantarum DNA were used as in Amanullah et al. (2014). The amplified fragments were subjected to electrophoresis 
Lee et al. ; Ioculant and Cutting Height on Barley Silage

(Mupid $^{\circledR}$-2plus Submarine-type electrophoresis system, TaKaTa, Inc., Japan) on $1.5 \%$ agarose gel and visualized after staining with ethidium bromide under UV illumination (Molecular Imager Gel Doc ${ }^{\mathrm{TM}} \mathrm{XR}+$ Imaging System, BioRad Laboratories, Inc., Hercules, CA, USA).

\section{Statistical Analyses}

This experiment was a conducted in completely randomized design with a $2 \times 2$ factorial arrangement. The data were analyzed using GLM procedure of SAS (2002), with a model containing cutting height (5 vs. $15 \mathrm{~cm})$, inoculant (no inoculant vs. inoculant) and interactions between them to analyze the data. The significance was declared at $\mathrm{p}<0.05$.

\section{RESULTS AND DISCUSSTION}

The chemical composition of the barley (Youngyang) forage before ensiling was shown in Table 1. The forage of 5 and $15 \mathrm{~cm}$ cutting heights had DM, CP, NDF and ADF contents of 26.5 vs. $28.0 \%$; 9.0 vs. $8.1 \%$; 54.6 vs. $55.5 \%$; 36.5 vs. $34.9 \%$, respectively. Barley forage cutted at $5 \mathrm{~cm}$ had numerically higher $\mathrm{CP}$ and $\mathrm{ADF}$ concentrations than at $15 \mathrm{~cm}$, but lower DM and NDF concentrations. The chemical compositions of barley forage used in this study were similar to the other studies (Kim et al., 2013; Amanullah et al., 2014). Generally, the lower part of the

Table 1. Chemical composition of barley silage (Youngyang) before ensiling (\%, DM)

\begin{tabular}{lcc}
\hline & \multicolumn{2}{c}{ Cutting height $^{1)}, \mathrm{cm}$} \\
\cline { 2 - 3 } & 5 & 15 \\
\hline \hline $\mathrm{DM}^{2)}$ & 26.5 & 28.0 \\
$\mathrm{CP}$ & 9.00 & 8.12 \\
$\mathrm{EE}$ & 2.74 & 3.35 \\
Curde ash & 6.84 & 7.32 \\
NDF & 54.6 & 55.5 \\
ADF & 36.5 & 34.9 \\
Hemicellulose & 18.6 & 20.5 \\
\hline
\end{tabular}

${ }^{1)}$ Forage were harvested at 5 and $15 \mathrm{~cm}$ height from root, respectively.

${ }^{2)} \mathrm{DM}$, dry matter; CP, crude protein; EE, ether extract; NDF, neutral detergent fiber; $\mathrm{ADF}$, acid detergent fiber. forage is considered to be highly lignified and poorly digestible (Tolera and Sundstøl, 1999). Bernard et al. (2004) reported that increase in cutting height reduce the ADF concentration. The chemical composition of barley silage after 100 days of ensiling were described in Table 2. Bacterial inoculation decreased $(\mathrm{p}=0.001)$ DM content, while increasing cutting height increased $(\mathrm{p}=0.002)$ DM content only in uninoculated silage. Interaction effect $(p=0.002)$ of cutting height and inoculation was observed in silage DM content. Neither inoculant, nor cutting height does affected ( $>0.05)$ CP content, however, interaction of inoculant and cutting height was observed $(\mathrm{p}<0.001)$. It was decreased by increasing cutting height in uninoculated silage (8.84 vs. $8.16)$, but increased in inoculated silage ( 8.19 vs 8.99$)$. Both $\operatorname{NDF}(p=0.011)$ and $\operatorname{ADF}(p=0.004)$ in silage were decreased by increasing cutting height. These results are in agreement with several earlier studies, where it was also reported that fiber content (NDF and/or ADF) of silages decreased by increasing cutting height of forage at harvest (Neylon and Kung, 2003; Kennington et al., 2005; Kung et al., 2008). As the lower part of the forage plants is more fibrous (Tolera and Sundstøl, 1999), so leaving some portion of that part at harvest resulting to lower down the fiber content of silage.

In vitro $\mathrm{DM}$ digestibility and fermentation characteristics in barley silage (Youngyang) at 100 days of ensiling are presented in Table 3. The IVDMD was increased (52.9 vs. $47.7 \% ; \quad \mathrm{p}=0.001)$ with the increase of cutting height. Increasing cutting height at harvest helps to improve digestibility of forage or silage by reducing the lignified lower part of the plant (Wu and Roth et al., 2005). The fiber of lower part of the plants is usually lignified and less digestible (Tolera and Sundstøl, 1999). In this study, it was also observed a significant reduction in fiber content (ADF, NDF) in silages of higher cutting height. Kennington et al. (2005) also observed increased DM disgetibility in higher cut silage upto $24 \mathrm{~h}$ of incubation. The $\mathrm{pH}$ was neither affected by inoculant, nor by cutting height $(\mathrm{p}>0.05)$ and was ranged from 4.75 to 4.78. Usually, bacterial inoculation with homolactic fermenters like $L$. plantarum helps to reduce silage $\mathrm{pH}$, which effect was not observed here. The silage $\mathrm{pH}$ is related with organic acid production, especially of lactic acid by epiphytic and inoculated bacteria 
Lee et al. ; Ioculant and Cutting Height on Barley Silage

Table 2. Chemical composition of barley silage (Youngyang) ensiled for $100 \mathrm{~d}(\%$, DM)

\begin{tabular}{|c|c|c|c|c|c|c|c|c|}
\hline & \multicolumn{2}{|c|}{ No inoculant } & \multicolumn{2}{|c|}{ Inoculant } & \multirow{2}{*}{ SEM } & \multicolumn{3}{|c|}{ Contrast $^{2)}$} \\
\hline & $5^{1)}$ & 15 & 5 & 15 & & Ino & Height & Ino*Height \\
\hline$\overline{\mathrm{DM}^{3)}}$ & 23.8 & 28.8 & 22.7 & 23.3 & 0.912 & 0.001 & 0.002 & 0.002 \\
\hline $\mathrm{CP}$ & 8.84 & 8.16 & 8.19 & 8.99 & 0.222 & 0.827 & 0.080 & 0.000 \\
\hline $\mathrm{EE}$ & 3.54 & 3.34 & 3.21 & 3.97 & 0.678 & 0.742 & 0.322 & 0.259 \\
\hline Curde ash & 2.75 & 2.33 & 2.37 & 2.20 & 0.191 & 0.022 & 0.034 & 0.299 \\
\hline NDF & 47.4 & 40.7 & 50.0 & 45.3 & 2.638 & 0.089 & 0.011 & 0.578 \\
\hline $\mathrm{ADF}$ & 32.7 & 24.9 & $34.0 \mathrm{a}$ & 27.0 & 3.084 & 0.832 & 0.004 & 0.838 \\
\hline Hemicellulose & 16.3 & 15.8 & 15.2 & 18.3 & 2.707 & 0.701 & 0.274 & 0.271 \\
\hline
\end{tabular}

1) Forage were harvested at 5 and $15 \mathrm{~cm}$ height from root, respectively.

${ }^{2)}$ Ino = inoculant effect; Height $=$ cutting height effect; Ino*Height $=$ interaction effect between inoculant and cutting height.

${ }^{3)} \mathrm{DM}$, dry matter; $\mathrm{CP}$, crude protein; EE, ether extract; NDF, neutral detergent fiber; ADF, acid detergent fiber.

Table 3. Fermentation indices of barley silage (Youngyang) ensiled for $100 \mathrm{~d}$ (\% of DM or as stated)

\begin{tabular}{|c|c|c|c|c|c|c|c|c|}
\hline & \multicolumn{2}{|c|}{ No inoculant } & \multicolumn{2}{|c|}{ Inoculant } & \multirow{2}{*}{ SEM } & \multicolumn{3}{|c|}{ Contrast $^{2)}$} \\
\hline & $5^{1)}$ & 15 & 5 & 15 & & Ino & Height & Ino*Height \\
\hline $\begin{array}{l}\text { IVDMD }^{3)}, \% \\
\end{array}$ & 46.4 & 55.7 & 48.9 & 50.1 & 0.907 & 0.061 & 0.001 & 0.001 \\
\hline $\mathrm{pH}$ & 4.75 & 4.78 & 4.76 & 4.76 & 0.072 & 0.984 & 0.815 & 0.621 \\
\hline Ammonia-N, \% & 0.28 & 0.22 & 0.32 & 0.33 & 0.022 & 0.001 & 0.265 & 0.042 \\
\hline Lactate, $\%$ & 3.96 & 3.02 & 2.87 & 4.85 & 0.674 & 0.489 & 0.044 & 0.005 \\
\hline Acetate, \% & 4.32 & 6.76 & 4.70 & 4.33 & 0.827 & 0.135 & 0.144 & 0.022 \\
\hline Propionate, \% & 0.69 & 0.49 & 0.74 & 0.48 & 0.104 & 0.857 & 0.001 & 0.255 \\
\hline La:Ac ratio & 0.91 & 0.47 & 0.54 & 1.12 & 0.177 & 0.059 & 0.246 & 0.001 \\
\hline
\end{tabular}

${ }^{1)}$ Forage were harvested at 5 and $15 \mathrm{~cm}$ height from root, respectively.

${ }^{2)}$ Ino = inoculant effect; Height $=$ cutting height effect; Ino*Height = interaction effect between inoculant and cutting height.

3) IVDMD, in vitro dry matter digestibility.

(Zahiroddini et al., 2004). In this study, overall lactic acid production was not affected by bacterial inoculation. Therefore, the $\mathrm{pH}$ of resulting silage remained unaffected. Bacterial inoculation increased the concentration of ammonia-N expressed both in percent of $\mathrm{DM}$ and total $\mathrm{N}(\mathrm{p}=0.001)$. The increase of ammonia-N in silage usually indicates proteolysis in silage and considered as loss of protein (Ohshima and McDonald, 1978). However, in this study, CP content of silages was not affected by bacterial inoculation. Though, there was difference in ammonia-N between inoculated and uninoculated silages ( 0.33 vs. $0.25 \%$; $\mathrm{p}=0.001$ ), but the amount was not significant to incur protein loss in silages. Cutting height affected lactate concentration ( 3.42 vs. $3.93 \% ; \mathrm{p}=0.044)$, and also interacted with bacterial inoculation $(\mathrm{p}=0.005)$. Propionate concentration was reduced in silage as the cutting height increased $(0.72$ vs. $0.49 \% ; \mathrm{p}=0.001)$. These effects of cutting height on barley silage are difficult to be discussed due to the limitation of available literature in this regard.

Microbial enumeration of LAB, yeast and mold in barley silage (Youngyang) at 100 days of ensiling are presented in Table 4. The LAB count was increased by both inoculation (7.11 vs. $6.47 \log 10 \mathrm{cfu} / \mathrm{g} ; \mathrm{p}=0.002)$ and higher cutting height ( 7.12 vs. $6.46 \log 10 \mathrm{cfu} / \mathrm{g} ; \mathrm{p}=0.002)$. This increase in LAB might be originated from $L$. plantarum inoculation in that group of silages. Yeast count was observed lower (6.01 vs. $6.83 \log 10 \mathrm{cfu} / \mathrm{g} ; \mathrm{p}=0.026)$ in uninoculated silage, but increased by increasing cutting height (6.84 vs. $6.01 \log 10$ $\mathrm{cfu} / \mathrm{g} ; \mathrm{p}=0.017)$. Numerically, the acetate concentration was higher in uninoculated silages that has greatest antimycotic effect among the short chain fatty acids in the resulting silages (Danner et al., 2003). Mold was neither affected by inoculation nor by cutting height $(\mathrm{p}>0.05)$.

The PCR analysis for L. plantarum DNA followed by 
Table 4. Microbial enumeration of lactic acid bacteria, yeast and mold in barley silage (Youngyang) ensiled for $100 \mathrm{~d}(\log 10 \mathrm{cfu} / \mathrm{g})$

\begin{tabular}{|c|c|c|c|c|c|c|c|c|}
\hline & \multicolumn{2}{|c|}{ No inoculant } & \multicolumn{2}{|c|}{ Inoculant } & \multirow{2}{*}{ SEM } & \multicolumn{3}{|c|}{ Contrast $^{2}$} \\
\hline & $5^{1)}$ & 15 & 5 & 15 & & Ino & Height & Ino*Height \\
\hline Lactic acid bacteria & 6.16 & 6.77 & 6.75 & 7.47 & 0.277 & 0.002 & 0.002 & 0.739 \\
\hline Yeast & 5.79 & 6.23 & 6.22 & 7.44 & 0.568 & 0.026 & 0.017 & 0.263 \\
\hline Mold & 4.30 & 4.07 & 4.33 & 4.98 & 0.452 & 0.145 & 0.382 & 0.155 \\
\hline
\end{tabular}

${ }^{1)}$ Forage were harvested at 5 and $15 \mathrm{~cm}$ height from root, respectively.

${ }^{2)}$ Ino = inoculant effect; Height $=$ cutting height effect; Ino*Height $=$ interaction effect between inoculant and cutting height.

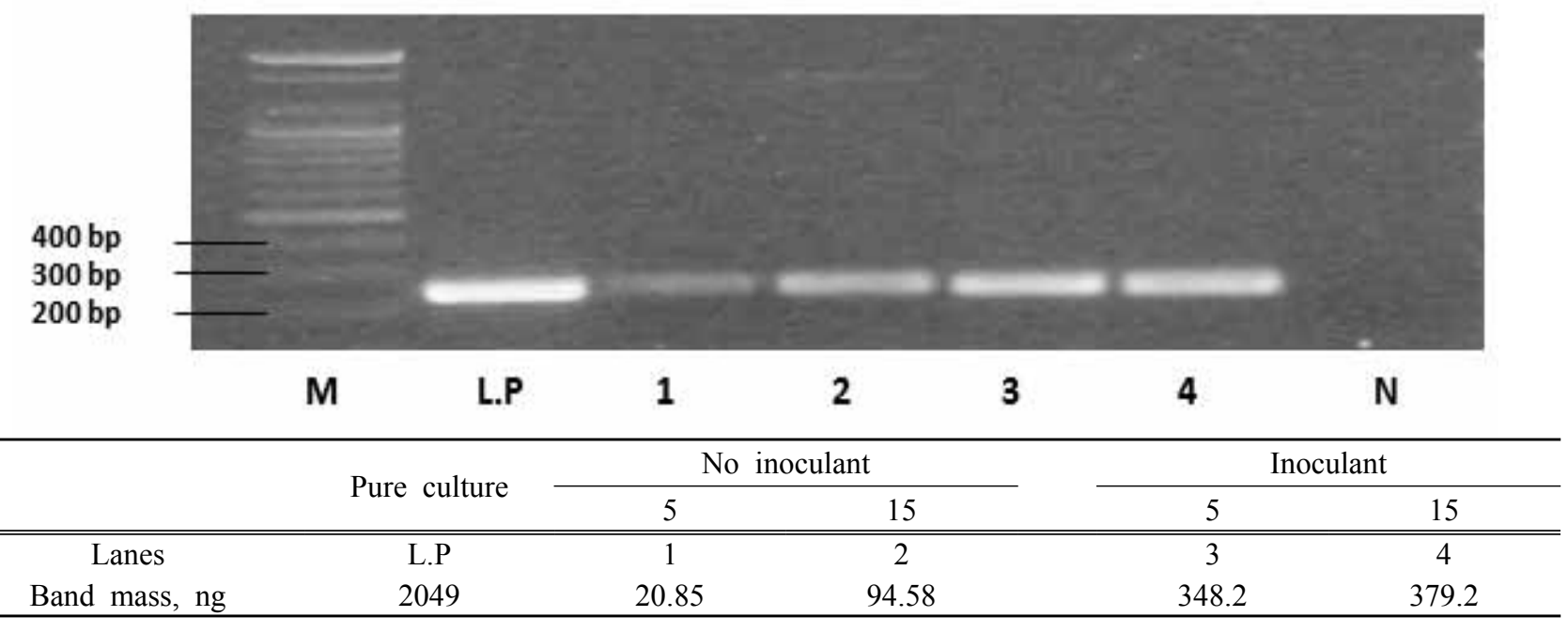

Fig. 1. Gel electrophoresis analysis and band mass after PCR amplification of DNA from barley silage (Youngyang) fermented for 100 day without or with inoculants: $M=$ DNA 100 bp size marker; L.P = Pure culture (L. plantarum, $1.2 \times 10^{3} \mathrm{cfu} / \mathrm{g}$ ); lane 1 to $4=5$ and $15 \mathrm{~cm}$ cutting height without or with inoculant; $\mathrm{N}=$ negative control.

gel electrophoresis indicated the L. plantarum dominated fermentation in inoculated silages (Fig. 1). The band mass (ng) of DNA extracted from L. plantarum indicated that increased numerically by inoculation (364 vs. $58 \mathrm{ng})$ and cutting height (237 vs. $185 \mathrm{ng}$ ).

\section{CONCLUSION}

It is concluded that increasing cutting height of forage at harvest is helpful to decrease fibrous portion but increase dry matter digestibility of silages. Bacterial inoculation did not bring any siginificant change in silage fermentation in this study. In some cases, the inoculated strain of bacteria may have some sort of antagonism and/or absence of synergism with the originally existed epiphytic bacteria on the plants. More detail study is needed in future to understand the effect of inoculation on silages of different cutting height.

\section{ACKNOWLEDGMENTS}

This research was carried out with support of Cooperative Research Program for Agriculture Science \& Technology Development (Project No. PJ906960) Rural Development Administration (RDA), Republic Korea and the authors (D. H. Kim and H. J. Lee) were supported by a scholarship from the BK21Plus Program, the Ministry of Education Korea.

\section{REFERENCES}

Amanullah, S.M., Kim, D.H., Lee, H.J., Joo, Y.H., Kim, S.B. and Kim, S.C. 2014. Effects of microbial additives on chemical composition and fermentation characteristics of barley silage. 
Lee et al. ; Ioculant and Cutting Height on Barley Silage

Asian Australatian Journal of Animal Science. 27:511-517.

AOAC. 1990. Official Method of Analysis, 15th ed. Association of Official Analytical Chemists, Arlington, Virginia, USA.

Baah, J., Addah, W., Okine, E.K. and McAllister, T.A. 2011. Effects of homolactic bacterial inoculant alone or combined with an anionic surfactant on fermentation, aerobic stability and in situ ruminal degradability of barley silage. Asian-Australasian Journal of Animal Science. 24:369-378.

Bernard, J.K., West, J.W., Tarmell, D.S. and Cross, G.H. 2004. Influence of corn variety and cutting height on nutritive value of silage fed to lactating dairy cows. Journal of Dairy Science. $87: 2172-2176$.

Chaney, A.L. and Marbach, E.P. 1962. Modified reagents for determination of urea and ammonia. Clinical Chemistry. 8: 130-132

Danner, H., Holzer, M., Mayrhuber, E. and Braun, R. 2003. Acetic acid increases stability of silage under aerobic conditions. Applied and Environmental Microbiology. 69:562-567.

Eun, J.S., Beauchemin, K.A., Hong, S.H. and Yang, W.Z. 2004. Effects of mechanical processing on the nutritive value of barley silage for lactating dairy cows. Journal of Dairy Science. 87:4170-4177.

Filya, I., Ashbell, G., Hen, Y. and Weinberg, Z.G. 2000 The effect of bacterial inoculants on the fermentation and aerobic stability of whole crop wheat silage. Animal Feed Science and Technology. 88:39-46.

Kennington, L.R., Hunt, C.W., Szasz, J.I., Grove, A.V. and Kezar, W. 2005. Effect of cutting height and genetics on composition, intake, and digestibility of corn silage by beef heifers. Journal of Animal Science. 83:1445-1454.

Kim, G.L., Kim, J.K., Qin, W., Jeong, J., Jang, S.S., Sohn, Y.S., Choi, C.W. and Song, M.K. 2012. Effects of feeding whole crop barley silage or whole crop rye silage based TMR and duration of TMR feeding on growth, feed cost and meat characteristics of Hanwoo steers. Korean Journal of Animal Sciece and Technology. 54:111-124.

Kim, S.B., Kim, D.H., Lee, H.J., Amanullah, S.M. and Kim, S.C. 2013. Effects of fermented persimmon extract supplements on chemical composition and fermentation characteristics of barley silage. Animal Science Journal. 84:403-408.

Kim, S.C. and Adesgoan, A.T. 2006. Influence of ensiling temperature, simulated rainfall, and delayed sealing on fermentation characteristics and aerobic stability of corn silage. Journal of Dairy Science. 89:3122-3132.

Kung, L.Jr., Moulder, B.M., Mulrooney, C.M., Teller, R.S. and Schimidt, R.J. 2008. The effect of silage cutting height on the nutritive value of a normal corn silage hybrid compared with brown midrib corn silage fed to lactating cows. Journal of Dairy Science. 91:1451-1457.

McDonald, P., Henderson, A.R. and Heron, S.J.E. 1991. The Biochemistry of Silage ( $2^{\text {nd }}$ ed.). Chalcombe Publications. Bucks. UK. pp. 9-12.

Muck, R.E. and Dickerson, J.T. 1988. Storage temperature effects on proteolysis in alfalfa silage. Transanction of the ASAE. 31:1005-1009.

Neylon, J.M. and Kung, L.Jr. 2003. Effects of cutting height and maturity on the nutritive value of corn silage for lactating cows. Journal of Dairy Science. 86:2163-2169.

Oba, M. and Allen, M.S. 1999. Evaluation of the importance of the digestibility of neutral etergent fiber from forage: Effects on dry matter intake and milk yield of dairy cows. Journal of Dairy Science. 82:589-596.

Ohshima, M. and McDonald, P. 1978. A review of the changes in nitrogenous compounds of herbage during ensilage. Journal of the Science of Food and Agricuture. 29:497-505.

SAS. 2002. Statistical Analysis Systems. SAS ${ }^{\circledR}$ User's guide: Statistics, Version 9. SAS Inst., Inc., Cary, NC.

Seale, D.R. 1986. Bacterial inoculants as silage additives. Journal of Applied Bacteriology. 61 (Suppl.): 9S-26S.

Seo, S., Kim, W.H., Kim, J.G., Choi, G.J., Kim, K.Y., Cho, W.M., Park, B.Y. and Kim, Y.H. 2010. Effect of whole crop barley silage feding on the growth performance, feed requirement and meat quality of Hanwoo steers. Journal of Korean Grassland and Forage Science. 30:257-266.

Tilley, J.M.A. and Terry, R.A. 1963. A two-stage technique for the in vitro digestion of forage crops. Journal of British Grassland Society. 18:104-111

Tolera, A. and Sundstøl, F. 1999. Morphological fractions of maize stover harvested at different stages of grain maturity and nutritive value of different fractions of the stover. Animal Feed Science and Technology. 81:1-16.

Van Soest, P.J., Robertson, J.B. and Lewis, B.A. 1991. Methods for dietary fiber, neutral detergent fiber and non-starch polysaccharides in relation to animal nutrition. Journal of Dairy Science. 74:3568-3597.

$\mathrm{Wu}, \mathrm{Z}$. and Roth, G. 2005. Considerations in managing cutting height of corn silage. Extension publication DAS 03-72. Pennsylvania State University, College Park.

Zahiroddini, H., Baah, J., Absalom, W. and McAllister, T.A. 2004. Effect of an inoculant and hydrolytic enzymes on fermentation and nutritive value of whole crop barley silage. Animal Feed Science and Technology. 117:317-330.

(Received August 1, 2014 / Revised September 1, 2014 / Accepted September 11, 2014) 